\title{
Detection of Intestinal Parasites in Diarrhea Samples Using Various Diagnostic Methods and Evaluation of the Stability of In-house Quality Control Materials for Stool Examination
}

Eun Jeong Won, Ji Seung Jung, Jun Hyung Lee, Hyun Jung Choi, Seung Jung Kee, Soo Hyun Kim, Myung Geun Shin, Jong Hee Shin, and Soon Pal Suh Department of Laboratory Medicine, Chonnam National University Medical School, Gwangju, Korea

Corresponding author: Eun Jeong Won Department of Laboratory Medicine, Chonnam National University Hospital, Chonnam National University Medical School, 42 Jebong-ro, Dong-gu, Gwangju 61469, Korea Tel: +82-62-220-5349

Fax: +82-62-224-2518

E-mail: Parasite.woni@chonnam. ac.kr
Background: Because of a lack of quality control (QC) materials, stool examination has not been standardised. This study examined intestinal parasites in diarrhea specimens to manufacture and evaluate the performance stability of QC materials for stool examination. Methods: This study examined diarrhea specimens submitted for stool culture. Microscopic examination was performed using the direct smear and formalin-ether concentration method (Military General Laboratory, MGL). Enzyme-linked immunosorbent assay (ELISA) kits (R-Biopharm AG, Germany) and xTAG Gastrointestinal Pathogen Panel (Luminex Corp., USA) were used for the three major protozoa: Cryptosporidium parvum, Giardia lamblia, and Entamoeba histolytica. Polymerase chain reaction (PCR) was performed for Dientamoeba fragilis and Blastocystis hominis. The QC materials for stool examination were generated using Diphyllobothrium nihonkaiense ova. The manufactured QC materials were evaluated under different storage conditions, with varying preservatives, temperatures, and storage times.

Results: From November 2015 to April 2016, 82 diarrhea specimens were collected and tested. All results from microscopy and ELISA were negative; $C$. parvum $(\mathrm{n}=2)$ and $G$. lamblia $(\mathrm{n}=1)$ were detected by xTAG, while $D$. fragilis $(\mathrm{n}=10)$ and $B$. hominis $(\mathrm{n}=2)$ were detected by PCR. High- and low-concentration QC materials were manufactured. Using the high-concentration QC material, ova were observed in all storage conditions using MGL. Using the low-concentration QC material, the ova were observed until 14 days, but not after 3 weeks.

Conclusions: It should be considered for making QC materials for stool examinations that focus on $D$. fragilis and $B$. hominis frequently found in Korea and with the caution to the low-concentration of QC materials could be unstable.

(J Lab Med Qual Assur 2017;39:90-96)

Key Words: Intestinal parasite, Diarrhea, Quality control material, Stability

Received January 26, 2017, Revision received March 16, 2017, Accepted March 17, 2017
서론

설사질환은 5 세 이하 소아 사망원인의 두 번째 흔한 원 인으로 임상적으로 중요한 질환 중 하나이며, 이 중 감염 성 설사가 전체 설사로 인한 사망원인 중 가장 흔하다. 특 히 장관감염성 원충류는 전 세계적으로도 설사질환을 야기
하는 주요 감염성 병원체 중 하나로 알려져 있으며, 작은와 포자충(Cryptosporidium parvum), 람블편모충(Giardia lamblia), 이질아메바(Entamoeba histolytica), 이핵아메바 (Dientamoeba fragilis) 등이 임상적으로 중요하다[1]. 국내에 서도 작은와포자충, 람블편모충, 이질아메바 등은 감염병의 예 방 및 관리에 관한 법률에서 지정감염병으로 관리되고 있다. 


\section{Journal of LABORATORY MEDICINE and QUALITY ASSURANCE}

Eun Jeong Won et al • Quality Control Materials for Stool Examination

2011년까지 국내에서 보고되었던 장관감염성 원충류 감염률 은 약 $2 \%$ 내외로 높지 않지만, 이들은 다소 민감도가 낮은 현 미경적 진단법 또는 효소면역검사법으로 조사된 것이었다[2]. 최근 보다 정확하고 민감한 기생충 감염증의 진단을 위해 중합 효소연쇄반응(polymerase chain reaction, PCR)을 기반으로 하는 진단법들이 소개되고 있다[3-6]. 하지만 아직까지 국내 에서는 장관감염성 원충을 포함하는 장내기생충 감염에 대한 관심도가 낮고, 검사실 수준에서 적절한 감시체계 역시 미비한 실정이다.

국내 장내기생충 유병률은 1970년대에는 84.3\%로 매우 높 았지만, 점차 감소하여 2013년에 이뤄진 감염실태조사에 따르 면 2.6\%에 이르렀다[7]. 현재 국내 임상검사실에서 장내기생 충에 대한 진단은 주로 현미경을 이용한 대변검경법을 이용하 고 있는데, 장내기생충의 유병률이 감소함에 따라 그 민감도 역시 감소하였다. 또한 현미경적 진단법은 관찰자에 따라 주관 적이며, 검경 경력에 따른 차이가 발생할 수 있다는 단점이 있 다. 일반 검사들과 마찬가지로 대변검경법 역시 검사실 간, 또 는 검사자 간 일관성 있는 검사를 위해 정도관리가 중요하지만 아직 국내에 활용 가능한 정도관리물질의 보급이 어려워 대변 검경법에 대한 정도관리는 미진한 실정이다.

이에 본 연구에서는 다양한 검사법을 적용하여 임상에 의뢰 되는 설사변에서 검출되는 국내 장내기생충 현황을 알아보고, 궁극적으로는 이를 기반으로 하여 대변검경에 이용 가능한 정 도관리물질을 제조하여 그 안정성을 평가하고자 하였다.

\section{재료 및 방법}

2015년 11월부터 2016년 4월까지 6개월간 2개 대학병원 진단검사의학과 검사실에 대변배양이 의뢰된 검체 중 설사 변을 대상으로 하였다. 현미경적 진단을 위해 포르말린-에 테르 침전법(Military General Laboratory formalin-ether concentration, MGL)을 시행하여 도말한 슬라이드를 관찰하 였으며, 원충 감염이 의심되는 경우에는 추가로 modified acidfast stain, trichrome stain을 시행하였다. 주된 장관감염성 원 충류인 람블편모충, 이질아메바, 작은와포자충의 진단을 위해 대변 내 항원에 대한 enzyme-linked immunosorbent assay (ELISA)를 시행하였으며, 각각 RIDASCREEN Giardia (R-Biopharm AG, Darmstadt, Germany), RIDASCREEN Entamoeba (R-Biopharm AG), RIDASCREEN Cryptosporidium (R-Biopharm AG) 키트를 사용하였다.

$\mathrm{PCR}$ 을 기반으로 하는 검사법을 적용하기 위해 설사변 검 체 $1 \mathrm{~g}$ 을 멸균된 $9 \mathrm{~mL}$ 인산완충용액(phosphate buffered saline, pH 7.4; Sigma-Aldrich, St. Louis, MO, USA) 에 넣고 진탕하여 부유된 가검물에서 Qiagen 자동핵산 추출장비(Qiagen, Hilden, Germany)를 이용하여 DNA 를 추출하였다. 람블편모충, 이질아메바, 작은와포자충 에 대해서는 상용화된 xTAG Gastrointestinal Pathogen Panel (Luminex Corp., Austin, TX, USA)을 이용하여 제 조사의 권장사항에 따라 증폭을 수행하였다. 이핵아메바 (Dientamoeba fragilis)에 대해서는 SSU 18S-rRNA 유전 자를 타깃으로 하는5'TATCGGAGGTGGTAATGACC-3' 전방 시발체와 5'CATCTTCCTCCTGCTTAGACG-3' 후 방 시발체를 이용하였으며, ready-to-use PCR reagent (Bioneer, Daejeon, Korea)에 $7 \mu \mathrm{L}$ distilled water, $2 \mu \mathrm{L}$ 시발체 쌍, $4 \mu \mathrm{L} \mathrm{DNA}$ 를 각각 넣었다. $\mathrm{PCR}$ 조건은 $94^{\circ} \mathrm{C} 4$ 분 1 회 후, $94^{\circ} \mathrm{C} 1$ 분, $58^{\circ} \mathrm{C} 1$ 분, $72^{\circ} \mathrm{C} 1$ 분을 38 회 반복하 고 마지막으로 $72^{\circ} \mathrm{C} 5$ 분으로 하였으며 최종적으로 $886 \mathrm{bp}$ 의 증폭산물을 확인하였다[8]. 블라스토시스티스 호미니스 (Blastocystis hominis)의 SSU rDNA유전자를 타깃으로 하 는 5'-GGAGGTAGTGACAATAAATC-3' 전방 시발체와 5' -TGCTTTCGCACTTGTTCATC-3' 후방 시발체를 이용하였 으며, $\mathrm{PCR}$ 조건은 기존 방법을 따랐다 [9]. $95^{\circ} \mathrm{C} 4$ 분 1 회 후, $95^{\circ} \mathrm{C} 30$ 초, $54^{\circ} \mathrm{C} 30$ 초, $72^{\circ} \mathrm{C} 30$ 초를 40 회 반복하고 마지막으 로 $72^{\circ} \mathrm{C} 5$ 분의 조건 후 $479 \mathrm{bp}$ 의 증폭산물을 확인하였다. 기 생충 진단을 위한 정도관리물질을 제조하기 위해 건강검진 목 적으로 내원하여 감염성 질환이 배제된 환자의 대변을 보존제 에 담아 $15 \mathrm{~mL}$ 로 만들고, 이에 동해긴촌충(Diphyllobothrium nihonkaiense)의 충란을 섞어 균질화시키는 방법을 사용하였 다. 먼저 충란액을 $40 \mathrm{ova} / 10 \mu \mathrm{L}$ 농도로 맞춘 후 $10 \%$ 포르말 린 용액 또는 sodium-acetate formalin (SAF) 보존제에 담은 정상 대변액 $15 \mathrm{~mL}$ 에 충란액 $500 \mu \mathrm{L}$ 을 섞어 고농도(500 ova) 정도관리물질을, 충란액 $100 \mu \mathrm{L}$ 을 섞어 저농도(100 ova) 정 도관리물질을 각각 제조하였다. 제조한 정도관리물질을 실온 $\left(25^{\circ} \mathrm{C}\right)$ 과 냉장보관 $\left(4^{\circ} \mathrm{C}\right)$ 상태로 구분하여 비교하였으며, 보관 기간은 당일, 7일 후, 14일 후, 21일 후, 28일 후, 3개월 후까지 보관하고, 직접검경법 및 MGL법을 시행하여 현미경으로 관 찰하였다.

\section{결과}

총 82 건의 설사변에 대해 현미경 검경법으로는 유의한 원 충류를 발견할 수 없었다. 설사 원인 원충류에 대한 선별 검사로 람블편모충, 이질아메바, 작은와포자충 등에 대한 ELISA를 시행한 결과 역시 82건 모두 음성이었다. xTAG 


\section{Journal of LABORATORY MEDICINE and QUALITY ASSURANCE}

Eun Jeong Won et al • Quality Control Materials for Stool Examination

Gastrointestinal Pathogen Panel을 이용한 결과, 작은와포자 충 2 건과 람블편모충 1 건의 양성 소견을 보였으며, $\mathrm{PCR}$ 검사 결과, 이핵아메바 양성 10건, 블라스토시스티스 호미니스 양 성 2건이 각각 관찰되었다(Table 1).

고농도 정도관리물질을 이용하여 MGL 검경 시 3개월 보관
시까지 2 가지 보존제 및 보관 온도와 무관하게 충란이 관찰되 었다. 직접 도말법 검경으로 3개 슬라이드를 관찰하였을 때, 포르말린으로 제조한 고농도 정도관리물질은 보관 온도와 무 관하게 3개월까지 충란이 관찰되었고, $\mathrm{SAF}$ 로 제조한 고농도 정도관리물질은 실온에서 3개월 보관한 검체에서만 충란이 관

Table 1. Detection of intestinal parasites that cause diarrhea in 84 specimens, using ELISA and PCR-based methods

\begin{tabular}{|c|c|c|c|}
\hline Diagnostics & Negative & Positive & Details \\
\hline Microscopy & 82 & 0 & \\
\hline $\begin{array}{l}\text { ELISA for Entamoeba histolytica, Giardia lamblia, and } \\
\text { Cryptosporidium parvum }\end{array}$ & 82 & 0 & \\
\hline PCR for Dientamoeba fragilis & 72 & 10 & \\
\hline PCR for Blastocystis hominis & 80 & 2 & \\
\hline xTAG for E. histolytica, G. lamblia, and C. parvum & 79 & 3 & C. parvum $(\mathrm{n}=2)$, G. lamblia $(\mathrm{n}=1)$ \\
\hline
\end{tabular}

Abbreviations: ELISA, enzyme-linked immunosorbent assay; PCR, polymerase chain reaction.

Table 2. Slide observation of the quality control materials containing high concentrations of ova

\begin{tabular}{|c|c|c|c|c|c|c|c|c|c|c|c|c|}
\hline \multirow{3}{*}{ Preservatives } & \multirow{3}{*}{$\begin{array}{c}\text { Storage } \\
\text { temperature }\end{array}$} & \multirow{3}{*}{$\begin{array}{l}\text { Storage } \\
\text { duration }\end{array}$} & \multicolumn{8}{|c|}{ No. of observed ova per slide } & \multicolumn{2}{|c|}{ Observation of ova } \\
\hline & & & \multicolumn{4}{|c|}{ Direct smear } & \multicolumn{4}{|c|}{ MGL } & \multirow{2}{*}{$\begin{array}{l}\text { Direct } \\
\text { smear }\end{array}$} & \multirow{2}{*}{ MGL } \\
\hline & & & 1 st & 2nd & 3rd & Average & 1 st & 2nd & 3 rd & Average & & \\
\hline \multirow[t]{11}{*}{$10 \%$ formalin } & $25^{\circ} \mathrm{C}$ & 0 day & 1 & 5 & 4 & 3 & 41 & 23 & 38 & 34 & Pass & Pass \\
\hline & & 7 day & 2 & 1 & 0 & 1 & 2 & 17 & 13 & 11 & Pass & Pass \\
\hline & & 14 day & 0 & 0 & 3 & 1 & 24 & 28 & 30 & 27 & Pass & Pass \\
\hline & & 21 day & 6 & 1 & 12 & 6 & 106 & 178 & 242 & 175 & Pass & Pass \\
\hline & & 28 day & 14 & 9 & 6 & 10 & 130 & 105 & 67 & 101 & Pass & Pass \\
\hline & & $3 \mathrm{mo}$ & 1 & 3 & 2 & 2 & 8 & 5 & 1 & 5 & Pass & Pass \\
\hline & $4^{\circ} \mathrm{C}$ & 7 day & 3 & 3 & 2 & 3 & 6 & 5 & 11 & 7 & Pass & Pass \\
\hline & & 14 day & 2 & 2 & 1 & 2 & 4 & 13 & 28 & 15 & Pass & Pass \\
\hline & & 21 day & 3 & 2 & 5 & 3 & 52 & 56 & 71 & 60 & Pass & Pass \\
\hline & & 28 day & 6 & 6 & 3 & 5 & 108 & 139 & 164 & 137 & Pass & Pass \\
\hline & & $3 \mathrm{mo}$ & 0 & 2 & 1 & 1 & 23 & 12 & 10 & 15 & Pass & Pass \\
\hline \multirow[t]{11}{*}{ SAF } & $25^{\circ} \mathrm{C}$ & 0 day & 1 & 2 & 3 & 2 & 39 & 20 & 24 & 28 & Pass & Pass \\
\hline & & 7 day & 3 & 0 & 2 & 2 & 15 & 15 & 16 & 15 & Pass & Pass \\
\hline & & 14 day & 5 & 0 & 2 & 2 & 2 & 8 & 8 & 6 & Pass & Pass \\
\hline & & 21 day & 1 & 1 & 0 & 1 & 12 & 10 & 7 & 10 & Pass & Pass \\
\hline & & 28 day & 10 & 0 & 6 & 5 & 91 & 75 & 117 & 94 & Pass & Pass \\
\hline & & $3 \mathrm{mo}$ & 0 & 0 & 0 & 0 & 6 & 3 & 8 & 6 & Fail & Pass \\
\hline & $4^{\circ} \mathrm{C}$ & 7 day & 3 & 0 & 0 & 1 & 6 & 2 & 4 & 4 & Pass & Pass \\
\hline & & 14 day & 1 & 1 & 0 & 1 & 24 & 23 & 19 & 22 & Pass & Pass \\
\hline & & 21 day & 6 & 3 & 9 & 6 & 52 & 20 & 30 & 34 & Pass & Pass \\
\hline & & 28 day & 3 & 7 & 3 & 4 & 34 & 35 & 45 & 38 & Pass & Pass \\
\hline & & $3 \mathrm{mo}$ & 1 & 1 & 0 & 1 & 5 & 7 & 5 & 6 & Pass & Pass \\
\hline
\end{tabular}

Abbreviations: MGL, Military General Laboratory, formalin-ether concentration method; SAF, sodium-acetate formalin. 


\section{Journal of LABORATORY MEDICINE and QUALITY ASSURANCE}

Eun Jeong Won et al • Quality Control Materials for Stool Examination

찰되지 않았다(Table 2). 포르말린으로 제조한 고농도 정도관 리물질을 실온에서 14 일 보관하였던 경우 3 개 중 1 개 슬라이 드에서만 충란이 관찰되었고, 실온에서 7일 보관하였던 검체 와 냉장으로 3 개월 보관하였던 검체에서는 3 개 중 2 개 슬라이 드에서 충란이 관찰되었다. $\mathrm{SAF}$ 로 제조한 고농도 정도관리물 질을 냉장에서 7 일 보관한 경우 3 개 중 1 개 슬라이드에서만 충 란이 관찰되었고, 실온에서 7일, 14일, 21일, 28일 보관하였던 검체와 냉장으로 14 일, 3 개월 보관한 검체에서는 3 개 중 2 개 슬라이드에서 충란이 관찰되었다. 저농도 정도관리물질의 경 우 14 일 보관 시까지는 2 가지 보존제, 보관 온도, 검경법과 무 관하게 충란이 관찰되었다. 하지만 MGL 검경 시라도 보존기 간 21일 이후로는 보존제 및 보관 온도와 상관없이 충란이 관 찰되지 않았다(Table 3). 포르말린으로 제조한 저농도 정도 관리물질을 실온에서 14 일 보관하였던 경우는 3 개 중 2 개 슬 라이드에서 충란이 관찰되었고, 냉장으로 7일, 14 일 보관하였
던 검체에서는 3 개 중 1 개 슬라이드에서 충란이 관찰되었다. $\mathrm{SAF}$ 로 제조한 저농도 정도관리물질을 실온에서 14일 보관한 경우에는 3 개 중 2 개 슬라이드에서 충란이 관찰되었다.

\section{고찰}

모든 검사를 수행하는 데 있어 오류를 감소시키고 나아가 환 자 검사결과에 대한 신뢰도와 타당성을 높이기 위해 정도관리 가 중요하다. 대변검경검사 역시 정도관리가 필요한 검사항목 이지만, 검사실에서 이용 가능한 적절한 정도관리물질의 부 재로 인해 실제적인 관리가 어려운 실정이다. 최근 러시아에 서 대변검경검사에 대한 외부정도관리를 가상슬라이드 판독 을 이용하여 시행하여 원충류나 크기가 작은 기생충 충란에 대 한 판독능력이 검사실마다 다양하고 일치율이 낮다고 보고하 였다[10]. 국내에서도 지난 2015년 신빙도조사사업에서 대변

Table 3. Slide observation of the quality control materials containing low concentrations of ova

\begin{tabular}{|c|c|c|c|c|c|c|c|c|c|c|c|c|}
\hline \multirow{3}{*}{ Preservatives } & \multirow{3}{*}{$\begin{array}{c}\text { Storage } \\
\text { temperature }\end{array}$} & \multirow{3}{*}{$\begin{array}{l}\text { Storage } \\
\text { duration }\end{array}$} & \multicolumn{8}{|c|}{ No. of observed ova per slide } & \multicolumn{2}{|c|}{ Observation of ova } \\
\hline & & & \multicolumn{4}{|c|}{ Direct smear } & \multicolumn{4}{|c|}{ MGL } & \multirow{2}{*}{$\begin{array}{l}\text { Direct } \\
\text { smear }\end{array}$} & \multirow{2}{*}{ MGL } \\
\hline & & & 1 st & 2nd & $3 r d$ & Average & 1 st & 2nd & 3 rd & Average & & \\
\hline \multirow{7}{*}{$10 \%$ formalin } & & 7 day & 1 & 2 & 1 & 1 & 8 & 5 & 13 & 9 & Pass & Pass \\
\hline & & 14 day & 1 & 0 & 1 & 1 & 3 & 3 & 8 & 5 & Pass & Pass \\
\hline & & 28 day & 0 & 0 & 0 & 0 & 0 & 0 & 0 & 0 & Fail & Fail \\
\hline & & $3 \mathrm{mo}$ & 0 & 0 & 0 & 0 & 0 & 0 & 0 & 0 & Fail & Fail \\
\hline & $4^{\circ} \mathrm{C}$ & 7 day & 1 & 0 & 0 & 0 & 105 & 25 & 61 & 64 & Pass & Pass \\
\hline & & 14 day & 0 & 0 & 1 & 0 & 8 & 1 & 3 & 4 & Pass & Pass \\
\hline & & 21 day & 0 & 0 & 0 & 0 & 0 & 0 & 0 & 0 & Fail & Fail \\
\hline \multirow[t]{9}{*}{ SAF } & $25^{\circ} \mathrm{C}$ & 0 day & 7 & 8 & 13 & 9 & 31 & 23 & 48 & 34 & Pass & Pass \\
\hline & & 7 day & 11 & 2 & 2 & 5 & 173 & 141 & 244 & 186 & Pass & Pass \\
\hline & & 14 day & 1 & 1 & 0 & 1 & 5 & 2 & 4 & 4 & Pass & Pass \\
\hline & & 21 day & 0 & 0 & 0 & 0 & 0 & 0 & 0 & 0 & Fail & Fail \\
\hline & & 28 day & 0 & 0 & 0 & 0 & 0 & 0 & 0 & 0 & Fail & Fail \\
\hline & & $3 \mathrm{mo}$ & 0 & 0 & 0 & 0 & 0 & 0 & 0 & 0 & Fail & Fail \\
\hline & $4^{\circ} \mathrm{C}$ & 7 day & 1 & 1 & 3 & 2 & 52 & 66 & 54 & 57 & Pass & Pass \\
\hline & & 14 day & 1 & 2 & 1 & 1 & 54 & 57 & 65 & 59 & Pass & Pass \\
\hline & & 21 day & 0 & 0 & 0 & 0 & 0 & 0 & 0 & 0 & Fail & Fail \\
\hline
\end{tabular}

Abbreviations: MGL, Military General Laboratory, formalin-ether concentration method; SAF, sodium-acetate formalin. 


\section{Journal of LABORATORY MEDICINE and QUALITY ASSURANCE}

Eun Jeong Won et al • Quality Control Materials for Stool Examination

검경검사에 대한 정도관리를 virtual slide 판독을 통해 시도한 바 있다[11]. 그 결과, 검사실에서 평소 접할 수 있는 편충란 에 대해서는 $98.4 \%$ 의 높은 정답률을 보였지만, 분선충 유충에 대해서는 $91.5 \%$, 대장아메바에 대해서는 $90.7 \%$, 왜소조충란 에 대해서는 낮은 일치도(46.5\%)를 보여 실제 검사실에서 다 양한 장내 기생충증에 대한 검경 경험의 부족으로 위양성 또는 위음성 결과를 보일 수 있음을 시사하였다[11]. 본 연구결과에 서는 설사를 일으키는 주된 장관 내 기생충 감염증으로 알려진 작은와포자충, 람블편모충, 이질아메바 외에도 이핵아메바 및 블라스토시스티스 호미니스가 흔히 발견되었다. 이핵아메바 와 블라스토시스티스 호미니스는 최근 여러 연구들에서 과민 성대장증후군의 원인으로 알려지면서 설사 환자에서 그 중요 성이 강조되고 있다[12]. 따라서 국내 임상검사실을 대상으로 이들에 대한 인식과 주의가 필요할 것으로 생각되며, 추후 제 작될 정도관리 검체에 이들을 포함시켜야 할 것으로 판단된다.

본 연구에서는 국내 장내기생충을 기반으로 대변검경에 이 용 가능한 정도관리물질을 제조하여 그 안정성을 평가하고 자 하였다. 국내 장내기생충의 비교적 낮은 감염률을 감안하 였을 때, 원충류를 포함하는 장내 기생충의 충분한 확보를 위 해 대변배양이 의뢰되는 검체 중에서도 특히 설사변을 대상 으로 하였다. 그럼에도 불구하고 현재 임상검사실에서 기생 충증 진단에 이용하는 현미경적 진단법으로는 장내 기생충의 진단민감도가 매우 낮은 것으로 나타났다. 특히 원충류에 대 해 현미경적 진단법이 상대적으로 낮은 민감도를 보일 수 있 음을 감안하여 [13], 추가적으로 ELISA 검사를 시행하였지 만 모두 음성 소견을 보였다. 그러나 이 중 3건에서는 xTAG Gastrointestinal Pathogen Panel에서 양성 소견을 보였고, 이는 ELISA 검사가 위음성 소견을 보일 수 있다는 다른 보 고와 유사한 결과였다[14]. 여러 연구자들이 주요 3종 원충류 의 진단에 있어서 상기 ELISA 키트의 유용성에 대해 검증하 였지만[15], 국내에서는 식품의약품안전처 허가 미비로 인해 환자 진단에 이용할 수 없는 실제적 한계가 있다. 반면 xTAG Gastrointestinal Pathogen Panel은 주요 3종 원충류뿐만 아 니라 다른 설사 원인세균 또는 바이러스를 동시에 검출할 수 있고, 이는 여러 보고에서 그 유용성이 검증된 바 있다 [16,17]. 최근 외국의 일반검사실에서는 보다 민감한 기생충 감염증 진 단을 위해 다양한 $\mathrm{PCR}$ 을 이용하는 진단법들이 실제로 적용 되고 있다[4-6]. 국내의 낮은 장내 기생충 감염률을 감안하면 $\mathrm{PCR}$ 을 기반으로 하는 진단법을 우선적으로 적용하는 것이 민 감도를 높이는 데 보다 도움이 될 것이다.

또한 본 연구에서는 대변검경에 이용 가능한 정도관리물질 을 제조하여 그 안정성을 평가하고자 하였는데, 기생충 진단
을 위한 대변검경용으로 $\mathrm{SAF}$ 와 $10 \%$ 포르말린 등 2 가지 보존 제를 이용하여 제조된 고농도 정도관리물질은 실온 $\left(25^{\circ} \mathrm{C}\right)$ 과 냉장보관 $\left(4^{\circ} \mathrm{C}\right)$ 모두 안정적이며, MGL법으로 검경 시에는 3 개월까지 검경 질이 유지됨을 알 수 있었다. 제조된 저농도 정 도관리물질은 14 일까지 검경 질이 유지되었으나, 21 일째부터 는 MGL법으로도 충란을 관찰할 수 없어 안정성이 낮아질 수 있음을 알 수 있었다. 또한 같은 농도로 제조한 정도관리물질 의 검경 시 관찰되는 충란 수 차이가 매우 커서 정량적 정도관 리로 이용하기에는 어려움이 있을 것으로 보였다. 하지만 대변 검경검사의 정성적 정도관리가 선행되어야 하는 것으로 감안 하여 고농도 정도관리물질의 제조가 1차적으로 이루어져야 할 것이며, 이를 위해서 상용되는 2 가지 보존제 모두 적합할 것으 로 판단되었다. 또한 국내의 낮은 장내 기생충 감염률을 감안 하여 일반검사실에서 대변검경 시 MGL법을 통한 대변농축이 필수적임을 주지시켜야 할 것이다.

본 연구는 설사 환자의 대변 검체에서 검출한 장내 기생충을 대상으로 하여 실질적인 국내 역학을 반영한 대변검경용 정도 관리물질을 제조하고자 하였다. 하지만 여러 보관 조건을 비교 검증할 만큼 충분한 검체를 확보하지 못하여 대변검경용 정도 관리물질의 제조에 장내 조충증 환자에서 얻어 교육용으로 보 관 중이던 충란을 이용하였다. 향후 흔한 장내 원충류의 실험실 적 배양을 이용한다면 다량의 원충류 검체를 확보하여 정도관 리물질을 보다 쉽게 제조할 수 있으리라 본다. 본 연구는 향후 대변검경검사의 정도관리물질의 표준화된 제조의 토대가 되고, 대변검경검사의 질 향상을 위한 바탕이 되리라 기대한다.

\section{감사의 글}

이 논문은 대한임상검사정도관리협회의 2016년 학술연구비 지원에 의해 이루어진 것이다.

\section{REFERENCES}

1. Verweij JJ, Blange RA, Templeton K, Schinkel J, Brienen EA, van Rooyen MA, et al. Simultaneous detection of Entamoeba histolytica, Giardia lamblia, and Cryptosporidium parvum in fecal samples by using multiplex real-time PCR. J Clin Microbiol 2004;42:1220-3.

2. Huh JW, Moon SG, Lim YH. A survey of intestinal protozoan infections among gastroenteritis patients during a 3-year period (2004-2006) in Gyeonggi-do (province), South Korea. Korean J Parasitol 2009;47:303-5. 


\section{Journal of LABORATORY MEDICINE and QUALITY ASSURANCE}

Eun Jeong Won et al • Quality Control Materials for Stool Examination

3. Won EJ, Kim SH, Kee SJ, Shin JH, Suh SP, Chai JY, et al. Multiplex real-time PCR assay targeting eight parasites customized to the Korean population: potential use for detection in diarrheal stool samples from gastroenteritis patients. PLoS One 2016;11:e0166957.

4. Verweij JJ, Mulder B, Poell B, van Middelkoop D, Brienen EA, van Lieshout L. Real-time PCR for the detection of Dientamoeba fragilis in fecal samples. Mol Cell Probes 2007;21:400-4.

5. Stark D, Al-Qassab SE, Barratt JL, Stanley K, Roberts T, Marriott D, et al. Evaluation of multiplex tandem real-time PCR for detection of Cryptosporidium spp., Dientamoeba fragilis, Entamoeba histolytica, and Giardia intestinalis in clinical stool samples. J Clin Microbiol 2011;49:257-62.

6. Verweij JJ. Application of PCR-based methods for diagnosis of intestinal parasitic infections in the clinical laboratory. Parasitology 2014;141:1863-72.

7. Ministry of Health and Welfare; Korea Association of Health Promotion. National survey of intestinal parasitic infections in Korea. Sejong: Ministry of Health and Welfare, 2013.

8. Stark D, Beebe N, Marriott D, Ellis J, Harkness J. Detection of Dientamoeba fragilis in fresh stool specimens using PCR. Int J Parasitol 2005;35:57-62.

9. Khoshnood S, Rafiei A, Saki J, Alizadeh K. Prevalence and genotype characterization of Blastocystis hominis among the Baghmalek people in southwestern Iran in 2013-2014. Jundishapur J Microbiol 2015;8:e23930.

10. Dovgalev AS, Astanina SY, Malakhov VN, Serdyuk AP, Imamkuliev KD, Gorbunova YP, et al. External quality assessment for the laboratory identification of the pathogens of parasitic diseases as an element for improving the postgraduate training of specialists. Med Parazitol (Mosk) 2016;(2):41-4.

11. Chang J, Kim MN, Kim EC, Shin JH, Lee NY, Kim S, et al. Annual report on the external quality assessment scheme for clinical microbiology in Korea (2015). J Lab Med Qual Assur 2016;38:169-93.

12. Yakoob J, Jafri W, Beg MA, Abbas Z, Naz S, Islam M, et al. Blastocystis hominis and Dientamoeba fragilis in patients fulfilling irritable bowel syndrome criteria. Parasitol Res 2010;107:679-84.

13. Jahan N, Khatoon R, Ahmad S. A comparison of microscopy and enzyme linked immunosorbent assay for diagnosis of Giardia lamblia in human faecal specimens. J Clin Diagn Res 2014;8:DC04-6.

14. ten Hove RJ, van Esbroeck M, Vervoort T, van den Ende J, van Lieshout L, Verweij JJ. Molecular diagnostics of intestinal parasites in returning travellers. Eur J Clin Microbiol Infect Dis 2009;28:1045-53.

15. Weitzel T, Dittrich S, Mohl I, Adusu E, Jelinek T. Evaluation of seven commercial antigen detection tests for Giardia and Cryptosporidium in stool samples. Clin Microbiol Infect 2006;12:656-9.

16. Zboromyrska Y, Hurtado JC, Salvador P, Alvarez-Martinez MJ, Valls ME, Mas J, et al. Aetiology of traveller's diarrhoea: evaluation of a multiplex PCR tool to detect different enteropathogens. Clin Microbiol Infect 2014;20:O753-9.

17. Wessels E, Rusman LG, van Bussel MJ, Claas EC. Added value of multiplex Luminex Gastrointestinal Pathogen Panel (xTAG GPP) testing in the diagnosis of infectious gastroenteritis. Clin Microbiol Infect 2014;20:O182-7. 
국내 설사변에서 다양한 진단법을 통한 장내 기생충 검출 및 대변검경용으로 제조한 정도관리물질의 안정성 평가 원은정 • 정지승 • 이준형 • 최현정 • 기승정 • 김수현 • 신명근 • 신종희 • 서순팔 전남대학교 의과대학 진단검사의학교실

배경: 현재 대변검경검사에서는 적절한 정도관리물질이 없어 질 관리가 미진한 실정이다. 본 연구의 목적은 설사변에서 발견되는 장내기생충 현황을 알아보고, 대변검경에 있어 활용 가능한 정도관리물 질을 제조하여 그 안정성을 검증하고자 하였다.

방법: 본 연구는 대변배양이 의뢰된 검체 중 82건의 설사변을 대상으로 하였다. 현미경적 진단법은 직접도말법과 포르말린-에테르 침전법으로 시행하였다. 작은와포자충, 람블편모충, 이질아메바에 대 해서는 enzyme-linked immunosorbent assay (ELISA) 키트(R-Biopharm, Germany) 및 XTAG Gastrointestinal Pathogen Panel (Luminex Corp., USA)을 이용하여 검사하였다. 이핵아메바와 블라스토시스티스 호미니스에 대해서는 특이 유전자를 타깃으로 하는 polymerase chain reaction (PCR)을 수행하였다. 정도관리물질은 음성 대변 검체와 동해긴촌충의 충란을 섞어 제조하였다. 제조 된 정도관리물질은 보존제 종류, 보관 온도, 보관 기간에 따라 안정성을 평가하였다.

결과: 총 82건의 설사변에서 현미경법으로는 유의한 기생충을 발견할 수 없었다. 작은와포자충, 람블 편모충, 이질아메바에 대한 ELISA 결과, 82건 모두 음성이었다. XTAG Gastrointestinal Pathogen Panel을 이용한 결과, 작은와포자충 2건과 람블편모충 1건의 양성 소견을 보였다. 이핵아메바와 블 라스토시스티스 호미니스 유전체에 대한 PCR 검사결과, 이핵아메바 양성 10건, 블라스토시스티스 호미니스 양성 2건이 관찰되었다. 본 연구에서 제조한 고농도 정도관리물질은 3 개월 보관 시까지 2 가지 보존제 및 보관 온도와 무관하게 충란이 관찰되었다. 저농도 정도관리물질의 경우, 14 일 보관 시까지는 2가지 보존제 및 보관 온도와 무관하게 충란이 관찰되었지만, 3주 이후에는 관찰되지 않았 다.

결론: 대변검경용 정도관리물질의 제조에 있어서 국내 설사환자에서 주로 발견되는 이핵아메바와 블 라스토시스티스 호미니스가 포함되는 것이 필요하고, 저농도 물질의 경우 안정성이 떨어질 수 있음을 감안하여야 할 것이다.

(J Lab Med Qual Assur 2017;39:90-96)

교신저자: 원은정

우)61469 광주시 동구 제봉로 42, 전남대학교 의과대학 전남대학교병원 진단검사의학과 Tel: 062)220-5349, Fax: 062)224-2518, E-mail: Parasite.woni@chonnam.ac.kr 